\title{
Protective role of the alpha-1-antitrypsin in intervertebral disc degeneration
}

Weikun Liu ${ }^{1}$ and Yanfu Wang ${ }^{2^{*}}$

\begin{abstract}
Background: Intervertebral disc degeneration is a complex disease with high prevalence. It suggests that cell death, senescence, and extracellular matrix degradation are involved in the pathogenesis. Alpha-1 antitrypsin (AAT), a serine protease inhibitor, was previously correlated with inflammation-related diseases. However, its function on intervertebral disc degeneration remains unclear.

Methods: A latex-enhanced immunoturbidimetric assay measured the serum level of AAT. Real-time polymerase chain reaction (RT-qPCR) and western blot were used to testify the expression of RNA and proteins related to cell apoptosis and the Wnt/B-catenin pathway. The animal model for intervertebral disc degeneration was built by disc puncture. The degeneration grades were analyzed by safranin o staining.

Results: We showed that alpha-1 antitrypsin could ameliorate intervertebral disc degeneration in vitro and in vivo. We also found that the serum alpha-1 antitrypsin level in Intervertebral disc degeneration patients is negative related to the severity of intervertebral disc degeneration. Moreover, alpha-1 antitrypsin was also showed to suppress tumor necrosis factor-alpha (TNF-a) induced WNT/B-catenin signaling pathway activation in human nucleus pulposus cells.
\end{abstract}

Conclusions: Our study provides evidence for AAT to serve as a potential therapeutic reagent for the treatment of intervertebral disc degeneration.

Keywords: Intervertebral disc degeneration, Alpha-1 antitrypsin, Apoptosis, Extracellular matrix degradation, WNT/ß-catenin signaling

\section{Introduction}

Low back pain (LBP) affects millions of people worldwide and leads to an enormous socioeconomic burden $[1,2]$. In the USA, spinal fusion surgery, with $\$ 12.8$ billion costs in 2011, was responsible for the highest aggregate hospital costs of any surgical procedure [3]. It was estimated that more than 480,000 lumbar discectomy cases occurring annually in the USA [4]. Although many efforts have been spent on preventing and treating this disorder, the underlying etiology and pathogenesis

\footnotetext{
* Correspondence: yanfu.wang1@hotmail.com

${ }^{2}$ Department of Rehabilitation Medicine, The Central Hospital of Wuhan, Tongji Medical College, Huazhong University of Science and Technology, Wuhan, Hubei, People's Republic of China

Full list of author information is available at the end of the article
}

mechanism remain incompletely understood. It is also urgent to explore a potential therapeutic method for the treatment.

Intervertebral disc (IVD) degeneration is a leading contributor to LBP. IVD are fibrocartilaginous cushions between spinal vertebrae, composed of an annulus fibrosus and a nucleus pulposus. The primary mechanism of IVD degeneration consists of the degradation of the extracellular matrix (ECM) and the degeneration of nucleus pulposus (NP). NP cells are the primary cell type in the NP; they play an essential role in tissue homeostasis inside the NP tissue. NP cells are rounded, "chondrocytelike" morphology; however, it has distinct phenotype and characteristics compared with chondrocytes [5]. 
a1-antitrypsin (AAT) was discovered in the mid-1950s but only came to prominence in 1963. It was identified as a potent serine protease inhibitor [6], with the highest affinity for neutrophil elastase (NE) [7]. AAT was produced by hepatocytes and secreted in the blood. It plays a central role in limiting local and systemic inflammation, and AAT concentrations rise 4-fold during infection and inflammation, remaining elevated up to 7 days, suggesting a function in host protection. Researchers have found that AAT is endowed with anti-inflammatory, analgesic, and chondroprotective properties partially interrelated. AAT has been shown to play a role in several conditions, like inflamed pancreatic islets, arthritis, autoimmune encephalomyelitis, and autoimmune encephalomyelitis [8,9].

As far as we know, this is the first study that explored the relationship between AAT concentrations and disease progression in IVD degeneration. Moreover, our results indicated that AAT contributes to IVD degeneration by alleviating NP cell apoptosis by regulating the Wnt/ $\beta$-catenin pathway. This study implied that AAT might serve as a novel serum marker for disease prediction and a potential therapeutic reagent for the treatment of IVD degeneration.

\section{Results}

AAT levels in IVD degeneration patients and controls

Serum AAT concentrations were found to be significantly lower in symptomatic IVD degeneration patients $(2.53 \pm 0.089 \mathrm{~g} / \mathrm{L})$, compared with asymptomatic healthy individuals $(2.797 \pm 0.081 \mathrm{~g} / \mathrm{L})$ (Fig. 1A). IVD degeneration severity was determined by participant's MRI scans, based on the Pfirrmann grading system [10]. It was found that serum AAT concentrations were highest in participants without disc degeneration. The serum
AAT level was significantly higher in patients with grade III degeneration than those with grade IV or V degeneration (Fig. 1B). Overall, our results showed that serum AAT levels were negatively correlated with the severity of IVD degeneration.

\section{AAT protects TNF-a-induced disc degeneration}

To determine the effect of AAT on the relative growth rate of TNF- $\alpha$-treated NP cells, a CCK- 8 assay was performed after $48 \mathrm{~h}$ of culture under basal conditions in the presence of $1,5,10,15$, or $20 \mu \mathrm{M}$ AAT after treating by $25 \mathrm{ng} / \mathrm{mL}$ TNF- $\alpha$ for $48 \mathrm{~h}$ or TNF- $\alpha$ alone. Results indicated that AAT effectively improved NP cells viability at $10 \mu \mathrm{M}$ concentrations (Fig. 2A). Therefore, we used an AAT concentration of $10 \mu \mathrm{M}$ in the following experiments. RT-qPCR showed $\mathrm{Bcl}-2$ expression decreased, but Bax expression increased in the TNF- $\alpha$ group compared with the AAT + TNF- $\alpha$ group (Fig. 2B). Western blots revealed the expression of cleaved caspase- 3 and Bax increased, but Bcl-2 decreased significantly in AAT-treated group compared with TNF- $\alpha$ alone group at the protein level (Fig. 2C, D). We next explored the effects of AAT on ECM. Our results showed that AAT could upregulate the expression of ECM synthesis genes: Aggrecan, COL2A1, and Collagen II, and significantly downregulate the expression of matrix-degrading enzymes: MMP-13, ADAMTS-5 (Fig. 2E). These findings indicated that AAT has a protective effect on the degenerated NP cells.

\section{AAT suppressing WNT/ $\beta$-catenin signaling pathway in NP cells}

The gene expression levels of Wnt1 and $\beta$-catenin increased significantly in TNF- $\alpha$ treated NP cells compared with untreated control NP cells. AAT treatment

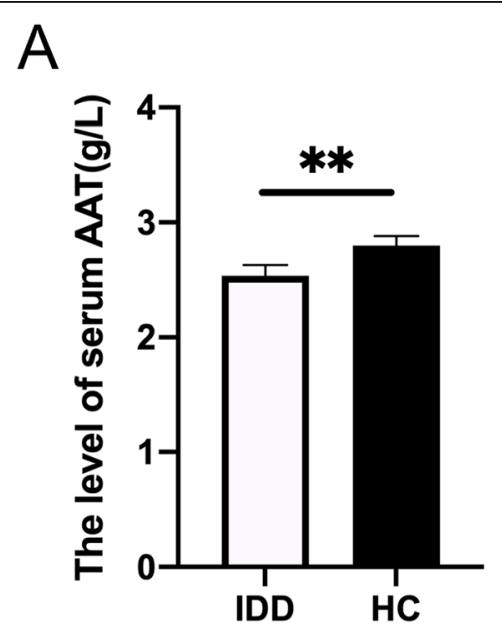

\section{B}

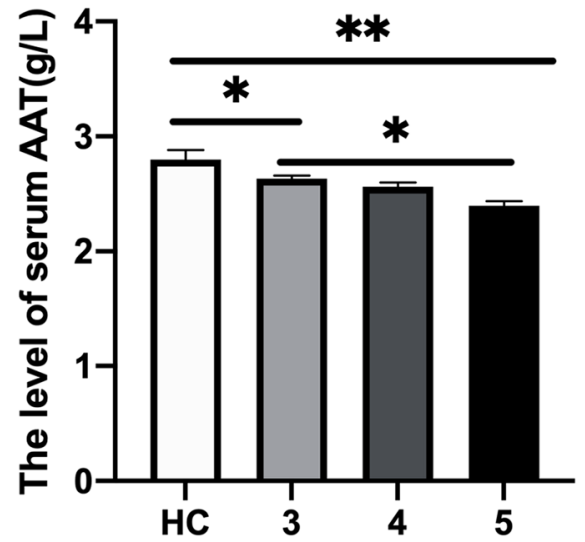

Fig. 1 A Comparison of serum levels of AAT between disc degeneration patients and control participants. B The serum level in disc degeneration patients with different disease severity, classified by Pfirmann grade. $\mathrm{HC}=$ healthy control. $N=15$ for each group. $\left({ }^{*} p<0.05,{ }^{* *} p<0.005,{ }^{* * *} p<0.001\right)$ 


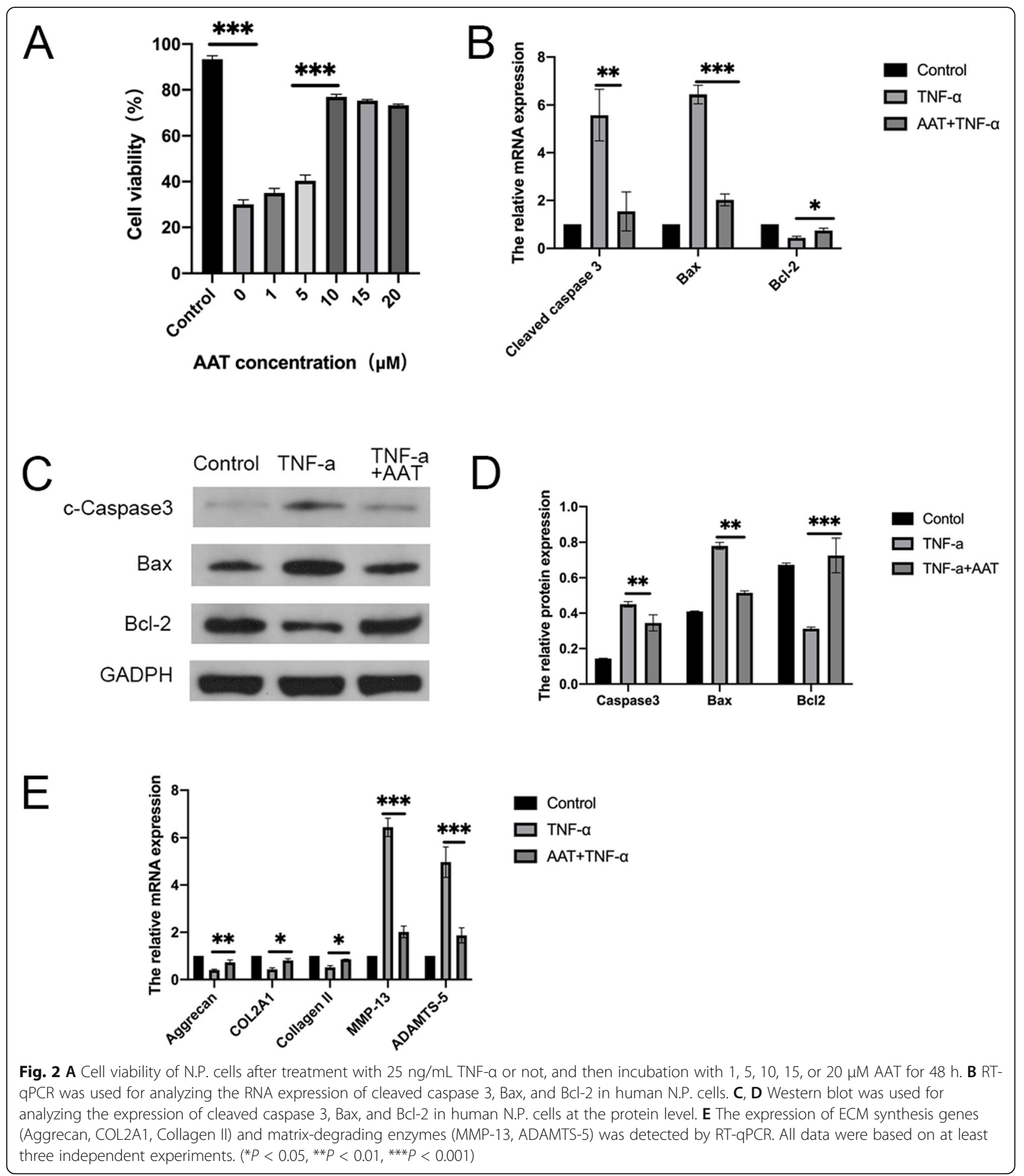

decreased the expression of both Wnt1 and $\beta$-catenin (Fig. 3A). The western blot analysis showed that TNF- $\alpha$ increased the level of Wnt1 and $\beta$-catenin. AAT treatment significantly inhibited the expression of these two proteins (Fig. 3B, C).

\section{AAT ameliorates IVD degeneration in vivo}

To further investigate the therapeutic effects of ATT on degenerated IVD degeneration, an animal model of IVD degeneration was used in our experiment. The IVD specimens from the above animal models were subjected 


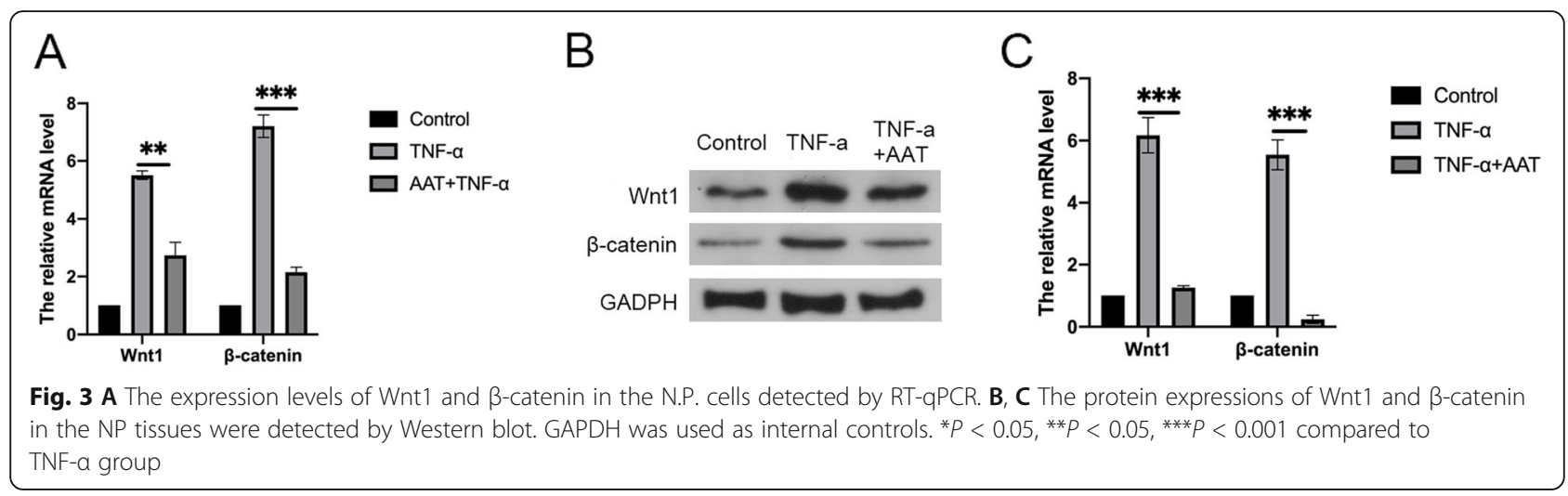

to histopathological analysis and scores. As shown in Fig. 4A, the PBS treated discs showed high glycosaminoglycan content. The oval-shaped NP occupied a large volume of the disc (>50\%) in the midsagittal crosssection. In TNF- $\alpha$-injected groups, the disc height decreased significantly. The safranine $O$ staining demonstrated the evident cells loss, NP/AF boundary disappeared and increased fibrillation in the NP area. However, in ATT administrated groups, the degenerative changes were alleviated compared with TNF- $\alpha$-injected groups. There was still some loose NP tissue (>25\%) with stellar-shaped cells and glycosaminoglycan content detected by safranine $\mathrm{O}$ staining. Moreover, the NP/AF boundary was still clear, and the height of the discs was moderate. We next evaluated the histopathological scores using a grading scale described previously [11] (Fig. 4B). These results indicated that ATT could ameliorate the TNF- $\alpha$ induced IVDD in vivo

\section{Materials and methods} Human samples

Normal human NP cells were obtained from patients with idiopathic scoliosis $(n=5$; average age, 26.8 years; range, $18-35$ years). Degenerative NP specimens were obtained from patients who were suffering from intervertebral disc degeneration caused by different conditions, including lumbar spinal stenosis, spondylolisthesis, and lumbar disc herniation.

\section{Serum analysis}

AAT (g/liter) concentrations were determined by latexenhanced immunoturbidimetric assay, a robust assay with perfectly comparable principles to those of nephelometry. $\alpha 1-\mathrm{AT}$ phenotypes were determined by isoelectric focusing in polyacrylamide gels at $\mathrm{pH}$ values between 3.5 and 5.0, using genomic DNA extracted from peripheral blood [12].
A

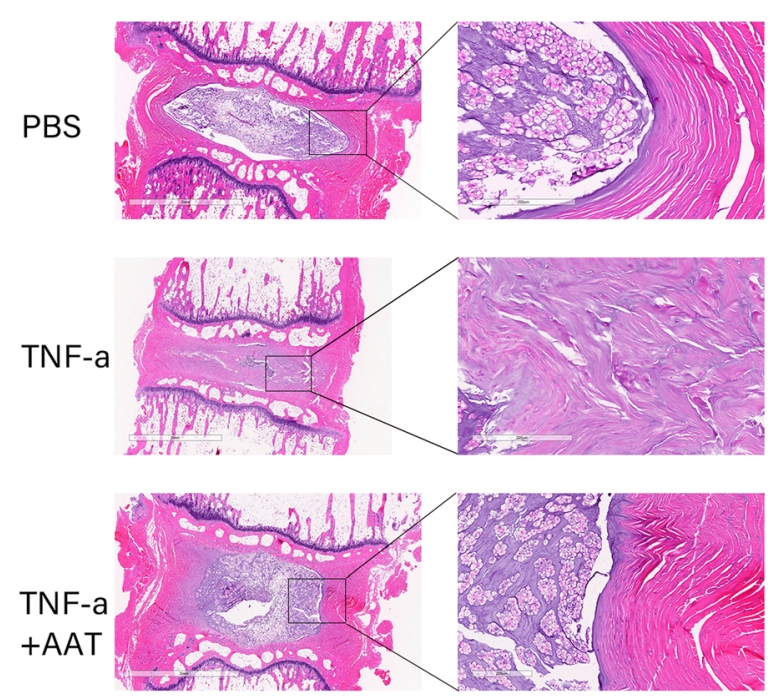

B

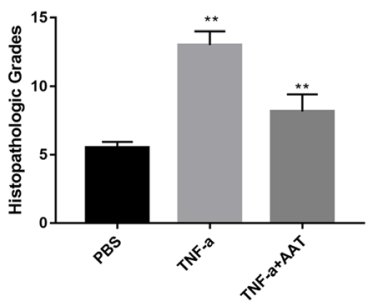

Fig. 4 The rat tail discs were injected with PBS, TNF-a (25 ng/mL), and TNF-a ( $25 \mathrm{ng} / \mathrm{mL}+\mathrm{ATT}(10 \mu \mathrm{M})$, maintained for $1 \mathrm{month}$. A Whole tail discs were observed using safranine $O$ staining. B Safranine $O$ staining images according to histological grading scale ${ }^{*} p<0.05$ versus PBS. ${ }^{*} p<0.05$ versus ATT 


\section{Isolation and culture of human IVD tissues}

This procedure was conducted as previously reported and performed under sterile conditions [13]. Human IVD tissues were derived from patients undergoing traumatic lumbar surgery. Briefly, the annulus fibrous and endplates were meticulously removed, and explants were cultured in DMEM/F-12 culture medium (HyClone, Thermo Co., USA) supplemented with $10 \%$ fetal bovine serum (FBS, Gibco, USA), 1\% $100 \mathrm{U} / \mathrm{mL}$ penicillin and $100 \mathrm{mg} / \mathrm{mL}$ streptomycin (HyClone, USA). The indicated culture groups were stimulated with TNF- $\alpha$ at 24 $\mathrm{h}$ after isolation as previously reported [14].

\section{Rat model establishment}

The rat IVD degeneration model was established as previously reported [15]. The area between the eighth and ninth coccygeal vertebrae (Co8-Co9) in rats was punctured using a 20-gauge needle. To make sure that the needle could not be punctured too deep, the length of the needle was decided according to the annulus fibrosus and the nucleus pulposus dimensions, which were measured in the preliminary experiment and found to be about $4 \mathrm{~mm}$. All the needles were kept in the disc for 1 min. AAT was diluted with normal saline to achieve a final AAT concentration of $10 \mathrm{mg} / \mathrm{ml}$. After surgery, the AAT solution was immediately injected intraperitoneally to deliver a dose of $50 \mathrm{mg} / \mathrm{kg} /$ day until the rats were killed. Daily monitoring of the rats was carried out to ensure their well-being, and all animals were allowed free unrestricted weight-bearing and activity.

\section{Cell viability assay}

NP cells viability were measured using a Cell Counting Kit (CCK-8, Dojindo, Japan) according to the manufacturer's instructions. NP cells were seeded in 96-well culture plates at a density of $2 \times 10^{3}$ cells per well. Ten microliters of CCK-8 solution was applied at specific time points; then, cells were incubated in the dark for 2 h at $37{ }^{\circ} \mathrm{C}$. Cell viability was assessed through absorbance detection at $450 \mathrm{~nm}$ using a spectrophotometer (ELx808 Absorbance Microplate Reader, Bio-Tek, USA).

\section{Real-time PCR}

Total RNA was extracted from human NP cells and tissues using TRIzol reagent (Ambion, Foster City, CA, USA) according to the manufacturer's instructions. The primers used for qRT-PCR were listed in Table 1. Total RNA was reverse transcribed using PrimeScript RT Master Mix (Takara Bio, Shiga, Japan) according to the manufacturer's instructions. qRT-PCR was performed using the One-Step SYBR PrimeScript RT-PCR Kit (Takara Bio) to quantify the RNA or mRNA expression levels of Bax, Bcl-2, Cleared Caspase-3, COL2A1, MMP13, ADAMTS-5, type II collagen, aggrecan, Wnt1, and $\beta$-catenin. Target mRNA expression levels were normalized against GAPDH. The relative expression levels were computed using the $2-\Delta \Delta \mathrm{Ct}$ method.

\section{Western blot analysis}

Proteins were extracted from NP cells using RIPA lysis buffer. Western blotting was carried out as described previously [16] with antibodies against the following proteins: cleaved caspase-3, B cell lymphoma-2(Bcl-2), B cell lymphoma-2 associated X (Bax), Cleared Caspase-3, Wnt1, and $\beta$-catenin. After initial incubation, the membrane was cultured with horseradish peroxidase (HRP)conjugated goat anti-rabbit secondary antibody (Boster, Wuhan, China). The grey value ratio of the target band to the reference band reflected the relative protein levels with GAPDH as the internal reference protein.

\section{Histopathologic analysis}

The rats were killed by an intraperitoneal overdosage injection of $10 \%$ chloral hydrate, and the tails were next harvested. The specimens were decalcified and fixed in formaldehyde, dehydrated, and embedded in paraffin.

Table 1 Sequences of primers used for quantitative real-time PCR

\begin{tabular}{|c|c|c|}
\hline Gene & Forward (5-3') & Reverse (5-3') \\
\hline $\mathrm{Bax}$ & AACTGGGGTCGATTGTG & GATCCAAGGCTCTAGGTGGTC \\
\hline $\mathrm{BCl}-2$ & TTGAGTTCGGTGGGGTCATG & GATCCAGGTGTGCAGATGCC \\
\hline Cleared Caspase-3 & TATGGAATTGATGGATAGT & CTGAAGAAACTAGTTAGTT \\
\hline Aggrecan & TCCAAACCAACCCGACAAT & TCTCATAGCGATCTITCTTCTGC \\
\hline COL2A1 & ACGCTCAAGTCGCTGAACAA & TCAATCCAGTAGTCTCCGCTCT \\
\hline Collagen II & GGGAATGTCCTCTGCGATGAC & GAAGGGGATCTCGGGGTTG \\
\hline MMP-13 & CCGAGGAGAAACAATGATCT & GCCTGTATCCTCAAAGTGAA \\
\hline ADAMTS-5 & CGACAAGAGTCTGGAGGTGAG & CGTGAGCCACAGTGAAAGC \\
\hline Wnt1 & GAATCGCCGCTGGAACTGTC & GCGGAGGTGATAGCGAAGATAAACG \\
\hline$\beta$-catenin & CAAGTGGGTGGTATAGAGG & AGTCCATAGTGAAGGCGAAC \\
\hline GAPDH & TCAAGAAGGTGGTGAAGCAGG & TCAAAGGTGGAGGAGTGGGT \\
\hline
\end{tabular}


The tissues were cut into $5-\mu \mathrm{m}$ sections. Slides of each disc were stained with safranine $O$. The cellularity and morphology of nucleus pulposus and annulus fibrosus were examined by another group of experienced histology researchers in a blinded manner using a microscope and evaluated by using a grading scale, as described previously [11]. The histologic score was 5 for the normal disc, 6-11 for moderately degenerated disc and $12-14$ for the severely degenerated disc.

\section{Statistical analysis}

Total data acquisition was conducted in a blinded manner. For comparisons of various treatment groups, the unpaired Mann-Whitney $t$ test paired Student's $t$ test, and 1-way or 2-way ANOVA (when appropriate) were performed. For ANOVA, Bonferroni post hoc analysis was used to compare treatment groups. All statistical analyses were performed with GraphPad Prism software (version 7.0; GraphPad Inc., La Jolla, CA, USA). The results are presented as the mean \pm standard deviation (S.D.) based on three independent experiments. The differences between groups were analyzed using the Student's $t$ test or one-way analysis of variance (ANOVA).

\section{Discussion}

Low back pain (LBP) is a common pathological condition, resulting in immense healthcare and socialeconomic burdens [17]. It has been widely acknowledged that intervertebral disc degeneration (IVD) is a major cause of LBP [18]. IVD consists of three conspicuous, including the inner gelatinous nucleus pulposus (N.P.), the outer annulus fibrosus (A.F.) and lower thin cartilages endplates (CEP) [19]. The degeneration of inner N.P. was found to be a significant important mechanism for IVD degeneration. N.P. is the central composite of IVD, rich in ECM. The ECM of N.P. is composed predominantly of type II collagen, proteoglycan aggregate, and aggrecan. Other numerous fewer components include biglycan, cartilage oligomeric matrix protein, decorin, and fibronectin [20]. Until now, the treatments for IVDD are relied on surgeries, like discectomy or spinal fusion procedures. Given the insufficient regenerative capacity for N.P. tissues, it is necessary to explore the biological method for alleviation or inhibiting the pathogenesis for IVD degeneration.

$\alpha 1$-antitrypsin (AAT) is a water-soluble and tissue diffusible circulating serine protease inhibitor. Previous studies showed that AAT could prevent tissue damage and inflammation via inactivating the serine protease elastase released by neutrophils [21]. The AAT concentration in plasma has previously been shown to increase in inflammation conditions, especially in the acute phase [22]. The level of AAT in a healthy individual is $0.9-2 \mathrm{~g} /$
L in plasma [23]. Some studies showed it might multiply 4-5 times in some acute inflammation and infection cases and increased in the third trimester of pregnancy or aging [23] AAT deficiency is one of the most important causes of chronic obstructive pulmonary disease (COPD) worldwide. Apart from respiratory diseases, the deficiency of AAT may also cause systemic vasculitis, panniculitis, type 2 diabetes mellitus, and spontaneous abortions [24]. In our study, we first showed that in IVD degeneration patients, the serum level of AAT decreased significantly compared to healthy individuals. These indicated that AAT presented a protective role for IVD degeneration.

Apoptosis, an essential type of IVD cell death, has been considered to play a crucial role in the process of degeneration [25]. Previously, studies showed that AAT has a direct pro-survival effect in apoptosis-dependent emphysema models [26]. Our data showed that AAT could inhibit the activity of caspase- 3 , the main executioner caspase involved in apoptosis, in the TNF- $\alpha$ induced NP cells degeneration model. Karina et al. showed intracytoplasmic uptake of AAT by lung endothelial cells revealed partial colocalization with caspase 3 [27]. The anti-apoptosis capacity of ATT providing the underlying mechanisms for its treatment potential. It was also suggested that AAT could inhibit the production of proinflammation cytokines, including IL-1beta and TNF- $\alpha$, and promoting the release of anti-inflammation cytokines, like IL-10 [28, 29]. During the process of IVDD, the inflammation cascade accelerates the pathogenesis. Given the capacity of ATT, it should also be possible that ATT may alleviate the generation of proinflammation cytokines. Further studies need to be conducted to show these hypotheses.

These protective effects for AAT were found to be associated with $\mathrm{Wnt} / \beta$-catenin signaling pathways in NP cells. This signal pathway plays a harmful impact on the health of IVD. Wnt proteins are important regulatory factors for IVD. The activation of Wnt/ $\beta$-catenin signaling could suppress proliferation and induce senescence in NP cells [30]. Tumor necrosis factor- $\alpha$ (TNF- $\alpha$ ) was found highly expressed in degenerative IVD tissues, and it was demonstrated deeply involved in IVDD pathogenesis, including extracellular matrix degeneration, apoptosis, and cell proliferation [31]. Here, we built an in vitro model of TNF- $\alpha$ induced NP degeneration. Seguin et al. reported that TNF- $\alpha$ reduced the synthesis of matrix molecules and upregulated the mRNA expression of MMP-1, -3, and -13 and ADAM-TS4 and ADAM-TS5 [32]. These data indicated that AAT could alleviate TNF- $\alpha$-induced cell apoptosis and ECM degeneration.

The Wnt/ $\beta$-catenin signaling pathway is a fundamental and evolutionarily conserved mechanism that directs cell 
proliferation, polarity, cell fate determination, and tissue homeostasis [33]. The interaction between TNF- $\alpha$ components and Wnt/ $\beta$-catenin signaling has also been analyzed.

It has been demonstrated that the Wnt/B-catenin pathway plays a significant role in chondrocyte proliferation and hypertrophy [34]. Moreover, the expression of SOX-9 and collagen II are elevated when the Wnt/ $\beta$-catenin pathway is inhibited. SOX-9 and collagen II are protective genes against chondrogenesis and disc degeneration [35,36]. Akihiko et al. founded the activation of $\mathrm{Wnt} / \beta$-catenin signaling can induce both NP cells degeneration and TNF- $\alpha$ activation, forming a positive feedback loop in NP cells [37]. When Wnt/ $\beta$-catenin signaling activates, NP cells' proliferation was suppressed, but the cellular senescence was accelerated during IVD degeneration [38]. Here, we showed ATT could be a reagent for stopping this positive feedback system in TNF- $\alpha$ stimulated NP cells. More experiments should be performed to understand the role of the $\mathrm{Wnt} / \beta$-catenin signaling pathway in NP cells.

In conclusion, the current study represents the first demonstration of the protective role of AAT in IVD degeneration, showed the possible mechanism by which ATT is targeting TNF- $\alpha$ induced Wnt signal pathway activation.

\section{Abbreviations}

AAT: Alpha-1 antitrypsin; TNF-a: Tumor necrosis factor-alpha;

IVD: Intervertebral disc; ECM: Extracellular matrix; N.P.: Nucleus pulposus;

NE: Neutrophil elastase; RT-qPCR: Real-time polymerase chain reaction

\section{Acknowledgements}

Not applicable.

\section{Authors' contributions}

WKL and YFW conceived and designed the study. WKL conducted the experiments and drafted the manuscript. YFW revised the manuscript and provided critical comments. All authors read and approved the final manuscript.

\section{Funding}

Not applicable.

\section{Availability of data and materials}

The data that support the findings of this study are available from the corresponding author on reasonable request.

\section{Declarations}

\section{Ethics approval and consent to participate}

The Ethics Committee approved the present protocols of our institute, and all patients had provided written informed consent before surgery. Animal ethics was obtained from our institute; the procedures were conducted based on 3Rs principles and adhere to animal research reporting standards.

\section{Consent for publication}

Not applicable

\section{Competing interests}

All authors declare that they have no competing interests.

\section{Author details}

'Department of Orthopedics, People's Hospital of Dongxihu District, Wuhan, Hubei, People's Republic of China. ${ }^{2}$ Department of Rehabilitation Medicine, The Central Hospital of Wuhan, Tongji Medical College, Huazhong University of Science and Technology, Wuhan, Hubei, People's Republic of China.

Received: 21 May 2021 Accepted: 11 August 2021

Published online: 20 August 2021

\section{References}

1. Li D, Zhu B, Ding L, Lu W, Xu G, Wu J. Role of the mitochondrial pathway in serum deprivation-induced apoptosis of rat endplate cells. Biochem Biophys Res Commun. 2014;452(3):354-60. https://doi.org/10.1016/j.bbrc.2014.08.054.

2. Walker BF, Muller R, Grant WD. Low back pain in Australian adults: the economic burden. Asia Pac J Public Health. 2003;15(2):79-87. https://doi. org/10.1177/101053950301500202.

3. Weiss AJ, Elixhauser A, Andrews RM. Characteristics of operating room procedures in U.S. hospitals, 2011: Statistical Brief \#170. Healthcare Cost and Utilization Project (HCUP) Statistical Briefs. Rockville (MD): Agency for Healthcare Research and Quality (US); 2006

4. Sherman J, Cauthen J, Schoenberg D, Burns M, Reaven NL, Griffith SL. Economic impact of improving outcomes of lumbar discectomy. The spine journal : official journal of the North American Spine Society. 2010;10(2): 108-16. https://doi.org/10.1016/j.spinee.2009.08.453.

5. LV F, Leung VYL, Huang $S$, et al. In search of nucleus pulposus-specific molecular markers. Rheumatology. 2013;53:600-10.

6. Potempa J, Korzus E, Travis J. The serpin superfamily of proteinase inhibitors: structure, function, and regulation. J Biol Chem. 1994;269(23):15957-60. https://doi.org/10.1016/S0021-9258(17)33954-6.

7. Bergin DA, Hurley K, McElvaney NG, et al. Alpha-1 antitrypsin: a potent antiinflammatory and potential novel therapeutic agent. Arch Immunol Ther Exp. 2012;60(2):81-97. https://doi.org/10.1007/s00005-012-0162-5.

8. Grimstein C, Choi YK, Satoh M, Lu Y, Wang X, Campbell-Thompson M, et al. Combination of alpha-1 antitrypsin and doxycycline suppresses collageninduced arthritis. J Gene Med. 2010;12(1):35-44. https://doi.org/10.1002/ jgm.1409.

9. Gao W, Zhao J, Kim H, Xu S, Chen M, Bai X, et al. a1-Antitrypsin inhibits ischemia reperfusion-induced lung injury by reducing inflammatory response and cell death. J Heart Lung Transplant. 2014;33(3):309-15. https:// doi.org/10.1016/j.healun.2013.10.031.

10. Pfirrmann CW, Zanetti M, Weishaupt D, et al. Subscapularis tendon tears: detection and grading at MR arthrography. Radiology. 1999;213(3):709-14. https://doi.org/10.1148/radiology.213.3.r99dc03709.

11. Mao HJ, Chen QX, Han B, Li FC, Feng J, Shi ZL, et al. The effect of injection volume on disc degeneration in a rat tail model. Spine (Phila Pa 1976). 2011;36(16):E1062-9. https://doi.org/10.1097/BRS.0b013e3182027d42.

12. Kueppers F. Determination of alpha1-antitrypsin phenotypes by isoelectric focusing in polyacrylamide gels. J Lab Clin Med. 1976:88(1):151-5.

13. Ellman MB, Kim JS, An HS, Chen D, KC R, An J, et al. Toll-like receptor adaptor signaling molecule MyD88 on intervertebral disk homeostasis: in vitro, ex vivo studies. Gene. 2012;505(2):283-90. https://doi.org/10.1016/j. gene.2012.06.004.

14. Johnson ZI, Shapiro IM, Risbud MV. RNA sequencing reveals a role of TonEBP transcription factor in regulation of pro-inflammatory genes in response to hyperosmolarity in healthy nucleus pulposus cells: a homeostatic response? J Biol Chem. 2016;291(52):26686-97. https://doi. org/10.1074/jbc.M116.757732.

15. Han B, Zhu K, Li FC, Xiao YX, Feng J, Shi ZL, et al. A simple disc degeneration model induced by percutaneous needle puncture in the rat tail. Spine (Phila Pa 1976). 2008;33(18):1925-34. https://doi.org/10.1097/BRS. Ob013e31817c64a9.

16. Kang $L$, Hu J, Weng $Y$, Jia J, Zhang $Y$. Sirtuin 6 prevents matrix degradation through inhibition of the NF-kB pathway in intervertebral disc degeneration. Exp Cell Res. 2017;352(2):322-32. https://doi.org/10.1016/j. yexcr.2017.02.023.

17. Katz JN. Lumbar disc disorders and low-back pain: socioeconomic factors and consequences. J Bone Joint Surg Am. 2006;88(Suppl 2):21-4.

18. Vergroesen PPA, Kingma I, Emanuel KS, Hoogendoorn RJW, Welting TJ, van Royen BJ, et al. Mechanics and biology in intervertebral disc degeneration: a vicious circle. Osteoarthr Cartil. 2015;23(7):1057-70. https://doi.org/10.1016/j. joca.2015.03.028. 
19. Tu J, Li W, Zhang Y, Wu X, Song Y, Kang L, et al. Simvastatin inhibits IL-1 $\beta$ induced apoptosis and extracellular matrix degradation by suppressing the NF-kB and MAPK pathways in nucleus pulposus cells. Inflammation. 2017; 40(3):725-34. https://doi.org/10.1007/s10753-017-0516-6.

20. Lu ZF, Doulabi BZ, Wuisman PI, et al. Influence of collagen type II and nucleus pulposus cells on aggregation and differentiation of adipose tissuederived stem cells. J Cell Mol Med. 2008;12(6b):2812-22. https://doi.org/1 0.1111/j.1582-4934.2008.00278.x.

21. de Serres F, Blanco I. Role of alpha-1 antitrypsin in human health and disease. J Intern Med. 2014;276(4):311-35. https://doi.org/10.1111/joim.12239.

22. 1965. Archivum Immunologiae et. Therapiae experimentalis. Annual report for 1964. Archivum immunologiae et therapiae experimentalis 13:Suppl:1-15.

23. Janciauskiene $\mathrm{S}$, Welte T. Well-known and less well-known functions of Alpha-1 Antitrypsin. Its role in chronic obstructive pulmonary disease and other disease developments. Annals of the American Thoracic Society. 2016; 13(Suppl 4):S280-8.

24. Gross B, Grebe M, Wencker M, et al. New Findings in PiZZ alpha1-antitrypsin deficiency-related panniculitis. Demonstration of skin polymers and high dosing requirements of intravenous augmentation therapy. Dermatology. 2009;218:370-5.

25. Ding $F, Z-W ~ S, L-m X$. Cell death in intervertebral disc degeneration. Apoptosis. 2013;18(7):777-85. https://doi.org/10.1007/s10495-013-0839-1.

26. Petrache I, Fijalkowska I, Zhen L, Medler TR, Brown E, Cruz P, et al. A novel antiapoptotic role for alpha1-antitrypsin in the prevention of pulmonary emphysema. Am J Respir Crit Care Med. 2006;173(11):1222-8. https://doi. org/10.1164/rccm.200512-1842OC.

27. Serban KA, Petrache I. Alpha-1 antitrypsin and lung cell apoptosis. Annals of the American Thoracic Society. 2016;13(Suppl 2):S146-9.

28. Lewis EC, Mizrahi M, Toledano M, DeFelice N, Wright JL, Churg A, et al. a1Antitrypsin monotherapy induces immune tolerance during islet allograft transplantation in mice. Proc Natl Acad Sci. 2008;105(42):16236-41. https:// doi.org/10.1073/pnas.0807627105.

29. Koulmanda M, Bhasin M, Hoffman L, Fan Z, Qipo A, Shi H, et al. Curative and $\beta$ cell regenerative effects of a1-antitrypsin treatment in autoimmune diabetic NOD mice. Proc Natl Acad Sci. 2008;105(42):16242-7. https://doi. org/10.1073/pnas.0808031105.

30. Hiyama A, Sakai D, Risbud MV, Tanaka M, Arai F, Abe K, et al. Enhancement of intervertebral disc cell senescence by WNT/ $\beta$-catenin signaling-induced matrix metalloproteinase expression. Arthritis Rheum. 2010;62(10):3036-47. https://doi.org/10.1002/art.27599.

31. Wang C, Yu X, Yan Y, Yang W, Zhang S, Xiang Y, et al. Tumor necrosis factor-a: a key contributor to intervertebral disc degeneration. Acta Biochim Biophys Sin. 2017;49(1):1-13. https://doi.org/10.1093/abbs/gmw112.

32. Séguin CA, Pilliar RM, Roughley PJ, Kandel RA. Tumor necrosis factora modulates matrix production and catabolism in nucleus pulposus tissue. Spine. 2005;30(17):1940-8. https:/doi.org/10.1097/01.brs.0000176188.40263.f9.

33. Logan CY, Nusse R. The Wnt signaling pathway in development and disease. Annu Rev Cell Dev Biol. 2004;20(1):781-810. https://doi.org/10.114 6/annurev.cellbio.20.010403.113126.

34. Moon RT, Kohn AD, De Ferrari GV, et al. WNT and beta-catenin signalling: diseases and therapies. Nat Rev Genet. 2004;5(9):691-701. https://doi.org/1 $0.1038 / \mathrm{nrg} 1427$.

35. Andrade AC, Nilsson O, Barnes KM, Baron J. Wnt gene expression in the post-natal growth plate: regulation with chondrocyte differentiation. Bone. 2007:40(5):1361-9. https://doi.org/10.1016/j.bone.2007.01.005.

36. Zhu M, Tang D, Wu Q, Hao S, Chen M, Xie C, et al. Activation of beta-catenin signaling in articular chondrocytes leads to osteoarthritis-like phenotype in adult beta-catenin conditional activation mice. Journal of bone and mineral research : the official journal of the American Society for Bone and Mineral Research. 2009;24(1):12-21. https://doi.org/10.1359/jbmr.080901.

37. Hiyama A, Yokoyama K, Nukaga T, Sakai D, Mochida J. A complex interaction between Wnt signaling and TNF-a in nucleus pulposus cells. Arthritis Research \& Therapy. 2013;15(6):R189. https://doi.org/10.1186/ar4379.

38. Hiyama A, Sakai D, Arai F, Nakajima D, Yokoyama K, Mochida J. Effects of a glycogen synthase kinase-3 3 inhibitor (LiCl) on c-myc protein in intervertebral disc cells. J Cell Biochem. 2011;112(10):2974-86. https://doi. org/10.1002/jcb.23217.

\section{Publisher's Note}

Springer Nature remains neutral with regard to jurisdictional claims in published maps and institutional affiliations.

\section{Ready to submit your research? Choose BMC and benefit from}

- fast, convenient online submission

- thorough peer review by experienced researchers in your field

- rapid publication on acceptance

- support for research data, including large and complex data types

- gold Open Access which fosters wider collaboration and increased citations

- maximum visibility for your research: over $100 \mathrm{M}$ website views per year

At BMC, research is always in progress.

Learn more biomedcentral.com/submissions 